\title{
Virus-induced changes in photosynthetic parameters and peroxidase isoenzyme contents in tomato (Solanum lycopersicum L.) plants
}

\author{
I.M. HUSEYNOVA ${ }^{+}$, S.M. MIRZAYEVA, N.F. SULTANOVA, D.R. ALIYEVA, N.SH. MUSTAFAYEV, \\ and J.A. ALIYEV
}

Institute of Molecular Biology and Biotechnology, Azerbaijan National Academy of Sciences, 2 A Matbuat Avenue, Baku AZ1073, Azerbaijan

\begin{abstract}
Tomato samples were collected from the field of Absheron peninsula in Azerbaijan in order to evaluate the incidence of main Tobamoviruses. According to results of serological and molecular tests, Tomato mosaic virus (ToMV), Tobacco mosaic virus (TMV), and Pepper mild mottle virus (PMMoV) were detected as single and mixed infections (TMV + $\mathrm{PMMoV}$; ToMV + PMMoV) in various tomato samples. It was found that Tobamovirus infection caused an increase in the content of malondialdehyde, alterations in the activities of peroxidase enzymes and quantitative and qualitative changes in their molecular isoforms. A comparison of thylakoid membrane polypeptides from virus-infected leaves indicated a decrease in the content of the thylakoid membrane polypeptides with molecular masses of 123, 55, 47, 33, 28-24, 17, and $15 \mathrm{kD}$. PSII efficiency and the content of chlorophylls $(a$ and $b)$ were significantly lower in the virus-infected leaves.
\end{abstract}

Additional key words: carotenoids; chlorophyll; lipid peroxidation; peroxidase activity; photosystem II efficiency; thylakoid membrane proteins; Tobamovirus.

\section{Introduction}

The tomato is, after the potato, the most consumed vegetable in the world, either fresh or after processing. It is grown at all latitudes under a variety of conditions, demonstrating useful variability and the effectiveness of the work done by plant breeders. Tobamovirus is an acronym for the range of viruses affecting the Solanaceae, brassicas, Malvaceae, and cucurbits. Tobamoviruses, such as Tobacco mosaic virus (TMV), Tomato mosaic virus (ToMV), and Pepper mild mottle virus (PMMoV) are widespread in tomato and significantly affect plant productivity by causing dangerous diseases in tomato crops. Currently, more than 45 viruses infecting tomato plants are known (Blancard 2012). A range of host plants and genome sequences are the main differences between these groups. There are very variable ways of the virus spreading among plants including seed contamination, mechanic translocation from plant to another plant or maybe with irrigation water in hydroponic culture (Broadbent 1976). Tobamovirus infection frequently causes chlorotic, mosaic or mottling symptoms in systematically infected tomato plants. All these morphological changes, leading to the reduction of chlorophyll (Chl) content, alterations in anatomical structure and chloroplast composition, affect phenotypical expression, which is closely linked to negative effects on photosynthesis. Biotic stress caused by virus infections especially affects protein content or manifests itself as oxidative stress leading to the intensive synthesis of reactive oxygen species (ROS). Plant antioxidant defense systems start functioning to decrease the synthesis of ROS, such as superoxide $\left(\mathrm{O}_{2}{ }^{--}\right)$, hydrogen peroxide $\left(\mathrm{H}_{2} \mathrm{O}_{2}\right)$, hydroxyl radicals $\left({ }^{\circ} \mathrm{OH}\right)$, and singlet oxygen $\left({ }^{1} \mathrm{O}_{2}\right)$ and prevent their damaging effects. Virus-host interactions under oxidative stress cause an enhancement of some specific physiological parameters protein oxidation, $\mathrm{H}_{2} \mathrm{O}_{2}$ accumulation, Chl bleaching, antioxidant system imbalance at the subcellular level, and damage to nucleic acids (Clarke et al. 2002, Díaz-Vivancos et al. 2006, Hernández et al. 2006).

Received 24 October 2016, accepted 20 April 2017, published as online-first 3 June 2017.

${ }^{+}$Corresponding author; e-mail: huseynova-i@botany-az.org

Abbreviations: APO - ascorbate peroxidase; BPO - benzidine-type peroxidase; Chl - chlorophyll; CMV - Cucumber mosaic virus; $\mathrm{F}_{0}$ - initial values of chlorophyll fluorescence; $F_{m}$ - maximal values of chlorophyll fluorescence; $F_{v} / F_{m}-$ maximal quantum efficiency of PSII; GPO - guaiacol-type peroxidase; LPO - lipid peroxidation; PMMoV - Pepper mild mottle virus; ROS - reactive oxygen species; TMV - Tobacco mosaic virus; ToMV - Tomato mosaic virus; TSWV - Tomato spotted wilt virus.

Acknowledgment: This work was supported by the Science Development Foundation under the President of the Republic of Azerbaijan - Grant № EIF-2014-9(24)-KETPL-14/11/3 and Grant № EIF/GAM-3-2014-6(21)-24/15/3. 
Furthermore, some authors have proposed that disturbances in the photosynthetic electron transport chain during viral pathogenesis enhance the generation of ROS in the chloroplasts and deterioration of chloroplast ultrastructure (Torres et al. 2006, Díaz-Vivancos et al. 2008). ROS synthesis is very important for the hostpathogen interaction (Torres et al. 2006, Oliveria et al. 2014, Rao et al. 2015). Nevertheless, the critical role of ROS in the elucidation of symptoms caused by pathogen has been studied insufficiently (Riedle-Bauer 2000, De Gara et al. 2003, Gullner et al. 2010). Contradictory results were reported in compatible plant-virus interactions regarding to activities of antioxidant enzymes (RiedleBauer 2000, Clarke et al. 2002, Helepciuca et al. 2014). However, there are some reports showing that virus infection affects electron transport rate in thylakoid membranes. Similarly, protein amount of the thylakoid membranes is one of the most sensitive components of the photosynthetic apparatus. The accumulation of several chloroplast proteins involved in both the photosynthetic electron transport chain and the Benson-Calvin cycle decreased in $N$. benthamiana plants upon infection with

\section{Materials and methods}

Plant material and serological diagnostics of virus diseases: Multiple phytopathological monitorings were carried out and 36 tomato samples with characteristic symptoms were collected from various gardens and greenhouses (at $20-25^{\circ} \mathrm{C}$ and $80 \%$ of relative humidity) at the Absheron peninsula during May-June in 2015. Samples were used immediately or rapidly frozen in liquid nitrogen, and stored at $-80^{\circ} \mathrm{C}$ until required. The collected tomato samples were tested using immunochromatography-ELISA and DAS-ELISA for the detection of ToMV, TMV, CMV, TSWV, PMMoV viruses (Bioreba $A G$, Sweden; and Agdia Inc., USA). For this purpose, extracts from leaf samples were prepared using extraction buffers according to the protocol and specific agristrips were tested for each virus. ELISA analysis was performed following the instruction of the manufacturer. The enzymatic reaction occurring on ELISA plate was first assessed visually by colour change. The absorbance values of infected and healthy plant samples were measured at $405 \mathrm{~nm}$ in an ELISA reader (Stat Fax Microplate, Awareness Technology, USA). According to primary results obtained by ELISA analysis, positive samples were from the tomato (Solanum lycopersicum L.) plants collected from the experimental field of the Azerbaijan Research Institute of Vegetable. Positive and healthy tomato samples were taken at the fruiting stage from the plants grown under the same natural conditions. Heights of healthy plants were approximately between 90 and $120 \mathrm{~cm}$. Length and width of leaves were $9.0-12.0 \mathrm{~cm}$ and $4.5-6.0 \mathrm{~cm}$, respectively. In case of infected plants, the minimum plant height was recorded for plants with mixed infections (60-90 cm and 55-85 cm, respectively), while
PMMoV-S (Pérez-Bueno et al. 2006, Pineda et al. 2010). According to Clarke et al. (2002), an increase in the ROS amount leads to rise in antioxidant enzyme activities, intensification of infectious diseases, replication of viruses, and their spread in the plant. Virus inoculation of tolerant and sensitive plant varieties has established that ROS activate the synthesis of antioxidant enzymes, which facilitates the increase of tolerance against viruses. Contents of main photosynthetic pigments $\mathrm{Chl} a$ and $\mathrm{Chl} b$ are known to decrease markedly. At the same time, amounts of carotenoids, which are responsible for solar energy uptake and deactivation of singlet oxygen, also increase due to viral infections (Takahashi et al. 2008). Viral infections lead to a decline in $\mathrm{CO}_{2}$ uptake and in accumulation of carbohydrates, and thereby to inhibition of the plant growth and development (Rahoutei et al. 2000, Sajnani et al. 2007).

The aim of this study was to clarify the effects of virus infection on photosynthetic pigments, PSII efficiency, and thylakoid membrane proteins and peroxidase activities in field-grown tomato plants.

the maximum height was observed in the TMV $(75-100 \mathrm{~cm})$ and ToMV $(65-95 \mathrm{~cm})$ infected plants.

\begin{tabular}{|c|c|c|c|c|}
\hline Group & Plant samples & $\begin{array}{l}\text { Plant height } \\
{[\mathrm{cm}]}\end{array}$ & $\begin{array}{l}\text { Leaf length } \\
{[\mathrm{cm}]}\end{array}$ & $\begin{array}{l}\text { Leaf width } \\
{[\mathrm{cm}]}\end{array}$ \\
\hline & Control (healthy) & $90-120$ & $9.0-12.0$ & $4.5-6.0$ \\
\hline 1 & TMV infected & $75-100$ & $7.0-10.0$ & $3.0-5.5$ \\
\hline 2 & ToMV infected & $65-95$ & $6.0-10.0$ & $3.0-5.0$ \\
\hline 3 & PMMoV infected & $60-95$ & $5.5-9.0$ & $2.5-4.0$ \\
\hline 4 & $\begin{array}{l}\text { TMV+PMMoV } \\
\text { infected }\end{array}$ & $60-90$ & $5.0-7.0$ & $2.5-3.5$ \\
\hline 5 & $\begin{array}{l}\text { ToMV+PMMoV } \\
\text { infected }\end{array}$ & $55-85$ & $4.5-6.0$ & $2.0-3.0$ \\
\hline
\end{tabular}

RNA extraction and reverse transcription PCR (RTPCR): Total RNA was extracted from 30-50 mg of fresh leaf tissue using the solution TriReagent (Life Technologies) according to the manufacturer's recommendation. After homogenizing the samples with Tri Reagent, chlorophorm was added and the homogenate was allowed to separate into a clear upper aqueous layer (containing RNA), an interphase and a red lower organic layer (containing the DNA and proteins). Isopropanol was used to precipitate RNA from the aqueous layer. DNA was precipitated from the interphase layer with ethanol. The obtained pellet was resuspended in Rnase-Purity and concentration of the extracted RNA samples were tested spectrophotometrically (Ultrospec 3300 PRO, Amersham, USA). Then the RNA samples were analysed with RT-PCR. RT-PCR was performed in the reaction mix containing $4 \mu \mathrm{l}$ of RNA, $1.5 \mu$ of Tobamovirus universal primer TobRT do2 (5' ACCGTTTTCGAACCGAGACT-3'), $1.5 \mu \mathrm{l}$ of dNTPs 
(25 mM), $4 \mu \mathrm{l}$ of RT (5x) buffer, $1 \mu \mathrm{l}$ of M-MLV (RT enzyme), $8 \mu \mathrm{l}$ of $\mathrm{ddH}_{2} \mathrm{O}$. The reaction was carried out for $1 \mathrm{~h}$ at $42^{\circ} \mathrm{C}$. In order to stop the reaction, the samples were kept at $65^{\circ} \mathrm{C}$ for $10 \mathrm{~min}$.

Amplification by PCR: After the electrophoretic analysis, RT-PCR products were tested using PCR method. The mixture containing $2.5 \mu \mathrm{l}$ of Tampon (10x), $3 \mu \mathrm{l}$ of $\mathrm{MgCl}_{2}$ $(50 \mathrm{mM}), 0.5 \mu \mathrm{l}$ of Tobamovirus universal primer [Tob RT up1 (5'-CGACATCAGCCGATGCAGC-3') and Tob RT do2 (5'-ACCGTTTTCGAACCGAGACT-3')], $3 \mu \mathrm{l}$ of dNTPs $(2.5 \mathrm{mM}), 13.7 \mu \mathrm{l}$ of dd $\mathrm{H}_{2} \mathrm{O}, 0.3 \mu \mathrm{l}$ of Tag polymerase (for one sample) was prepared for the reaction. The volume of the total reaction mixture for one sample was $25 \mu \mathrm{l}(5 \mu \mathrm{l}$ of RNA sample $+20 \mu \mathrm{l}$ of the reaction mixture). PCR reaction volume was $25 \mu \mathrm{l}$ and amplification conditions were as follows: $95^{\circ} \mathrm{C}$ for $5 \mathrm{~min},\left(35\right.$ cycles at $94^{\circ} \mathrm{C}$ for $1 \mathrm{~min}, 65^{\circ} \mathrm{C}$ for $45 \mathrm{~s}, 70^{\circ} \mathrm{C}$ for $1 \mathrm{~min}$ ) and a final extension at $72^{\circ} \mathrm{C}$ for $10 \mathrm{~min}$. Following PCR, $10 \mu \mathrm{l}$ of the product was electrophoresed on a $1 \%$ agarose gel, stained with ethidium bromide and recorded digitally using UV-Gel Doc system (UK). After detection of viruses, selected samples were used for the following analysis.

Lipid peroxidation: Intensity of lipid peroxidation was evaluated according to the content of the compound interacting with 2-thiobarbituric acid (basically MDA), using for the analysis homogenate prepared in Tris- $\mathrm{HCl}$ buffer (pH 7.6) (Heath and Packer 1968). Supernatant absorbance was measured at $532 \mathrm{~nm}$ (Ultrospec 3300 PRO, Amersham, USA). Extinction coefficient of $155 \mathrm{mM}^{-1} \mathrm{~cm}^{-1}$ was used for the estimation of MDA concentration.

Isolation of the enzyme extract: To obtain the total cell extract, tomato leaves were homogenized in a medium containing $1 \mathrm{mM}$ EDTA (pH 8.0), $2 \mathrm{mM}$ phenylmethylsulfonyl fluoride (PMSF), $1 \%$ PVP, $100 \mathrm{mM}$ Naphosphate buffer ( $\mathrm{pH} 7.8), 0.1 \%$ Triton X-100, $2 \mathrm{mM}$ ascorbate, then filtered, and centrifuged for $20 \mathrm{~min}$ at $15,000 \times g$. The resulting supernatant was used for analysis of peroxidase enzymes.

Activity of peroxidases: The activities of the studied enzymes in leaves of tomato were assessed spectrophotometrically (Ultrospec 3300 PRO, Amersham, USA) at a linear reaction. Three different samples for each treatment were taken and analyzed twice.

Activity of ascorbate peroxidase (APO, EC 1.11.1.11) was determined by the method of Nakano and Asada (1981) with some modifications. The method is based on the determination of the rate of decomposition of hydrogen peroxide by ascorbate to form water and dehydroascorbate. Optical density was recorded in a spectrophotometer at $290 \mathrm{~nm}$. The activity was calculated in $\mu$ mol(ascorbate) $\mathrm{mg}^{-1}$ (protein) $\mathrm{min}^{-1}$ based on a molar extinction coefficient: $\varepsilon=2.8 \mathrm{mM}^{-1} \mathrm{~cm}^{-1}$.
Activity of the guaiacol-type peroxidase (GPO, EC 1.11.1.7) was determined by the change in optical density of the reaction mixture for $3 \mathrm{~min}$ at $470 \mathrm{~nm}$ (Mahalingam et al. 2005). GPO activity was calculated as $\mu \mathrm{mol}$ (oxidized guaiacol) $\mathrm{mg}^{-1}$ (protein) $\mathrm{min}^{-1}$ considering the extinction coefficient: $\varepsilon=26.6 \mathrm{mM}^{-1} \mathrm{~cm}^{-1}$

Activity of the benzidine-type peroxidase (BPO EC 1.11.1.7.) was measured by the increase in optical density of the reaction mixture for $1 \mathrm{~min}$ at $590 \mathrm{~nm}$ (Gechev et al. 2002). The activity was calculated in $\mu$ mol(benzidine product) $\mathrm{mg}^{-1}$ (protein) $\mathrm{min}^{-1}$ considering extinction coefficient: $\varepsilon=39 \mathrm{mM}^{-1} \mathrm{~cm}^{-1}$.

Peroxidase isoenzyme contents: Qualitative changes in the enzyme activities were determined using a vertical native PAGE ( $7 \%$ for BPO and GPO, $10 \%$ for APO) according to the method of Davis (Davis 1964). Electrophoresis was carried out for $3 \mathrm{~h}$ at $4{ }^{\circ} \mathrm{C}$ with a steady current of $30 \mathrm{~mA}$, using the device SE 250 (Amersham Biosciences, USA). Staining of APO was performed by the method of Mittler and Zilinskas (1993), GPO using the method of Radotic et al. (2000), and BPO by the method of Cuypers et al. (2002).

Protein content: Total protein was determined by the Bradford method (Bradford 1976). Bovine serum albumin was used to construct the calibration curve.

Photochemical activity associated with photosynthetic electron transport in the plant leaves was estimated by a flurometer Mini-PAM (WALZ, Germany). The initial $\left(\mathrm{F}_{0}\right)$ and maximal $\left(\mathrm{F}_{\mathrm{m}}\right) \mathrm{Chl}$ flurorescence were determined, and a relative fluorescence ratio of $\left(\mathrm{F}_{\mathrm{m}}-\mathrm{F}_{0} / \mathrm{F}_{\mathrm{m}}\right)$ was considered as photochemical activity of PSII.

Chls and carotenoids (Car): The Chl content was determined following the method of McKinney (1941). Chl concentration was determined in $80 \%$ acetone extract. Absorbance of the supernatant was recorded at 663, 645, and $450 \mathrm{~nm}$ by Ultrospec 3300 PRO (Amersham, USA).

$$
\begin{aligned}
& \text { Chl } a=9.784 \mathrm{D}_{662}-0.990 \mathrm{D}_{664} \\
& \text { Chl } b=21.426 \mathrm{D}_{644}-4.650 \mathrm{D}_{662} \\
& \text { Chl } a+b=5.134 \mathrm{D}_{662}-20.436 \mathrm{D}_{664} \\
& \text { Car }=4.695 \mathrm{D}_{440,5}-0.268 \mathrm{Chl}(a+b)
\end{aligned}
$$

The Chl stability index (CSI) was determined according to Sairam et al. (1997) and calculated as follows:

$\mathrm{CSI}=($ total $\mathrm{Chl}$ under stress $/$ total Chl under control $) \times 100$.

Isolation of thylakoid membranes and electrophoretic analysis: Leaves were crushed and homogenized with blender (Waring Laboratory, UK) four times for 1-2 $\mathrm{min}$ in a chilled environment to isolate chloroplast $(1: 4, \mathrm{w} / \mathrm{v})$ with buffer containing $0.4 \mathrm{M}$ sucrose, $20 \mathrm{mM}$ 
Tris $\mathrm{pH} 7.8,10 \mathrm{mM} \mathrm{NaCl}, 1 \mathrm{mM}$ EDTA $\mathrm{Na}_{2}, 1 \mathrm{mM}$ sodium ascorbate, and $0.1 \%$ PEG following the procedure according to Aliyev et al. (1992). The homogenate was filtered twice through four layers of cheesecloth. The filtrate was centrifuged at 2,000 $\times \mathrm{g}$ for $5 \mathrm{~min}$ and then supernatant was centrifuged at $1,000 \times g$ for $10 \mathrm{~min}$ and the resulting chloroplast pellet was homogenized in a small volume of hypotonic buffer containing $10 \mathrm{mM}$ $\mathrm{MgCl}_{2} \cdot 6 \mathrm{H}_{2} \mathrm{O}, 50 \mathrm{mM}$ Tris- $\mathrm{HCl}$ buffer, $\mathrm{pH}$ 7.2. The pelleted thylakoid membranes were resuspended with $5 \mathrm{mM}$ Tris- $\mathrm{HCl}$ ( $\mathrm{pH} 8.0)$. All steps were carried out at $4^{\circ} \mathrm{C}$.

Analysis of the polypeptide composition of the samples and the determination of the molecular mass of protein

\section{Results}

During the surveys, samples from virus-like symptomatic plants were collected (Fig. 1). Symptomless plants were also sampled as negative health control.

Viral diseases, expressed by symptoms of leaf deformation and discolouration, leaf distortion, bubbly, yellowing, mottling, and different mosaic patterns were observed. According to the results of immunochromatography-ELISA and DAS-ELISA tests, ToMV, TMV, and PMMoV related to Tobamoviruses were detected as single and mixed infections (TMV + PMMoV, ToMV + PMMoV) in various tomato samples (Table 1). The incidence of the examined viruses provided from various gardens and greenhouses were $26.3 \%$ for ToMV, $22.5 \%$ for $\mathrm{TMV}, 8.1 \%$ for PMMoV, and $2.5 \%$ for the mixed infection of Tobamovirus. The incidence of these viruses in the personal commercial gardens was higher than the rates in the various collections from experimental field. ELISA-based diagnosis of ToMV, TMV, and PMMoV in all tested tomato samples showed $34.2 \%$ of infected plants. Results showed that ToMV, TMV, and PMMoV were widely spread in tomato plants from the Absheron peninsula. The results of the ELISA-based detection completely coincided with ones of the RT-PCR analysis. RT-PCR results showed that the same amount of plants subunits were performed by analytical electrophoresis on SDS linear gradient (10-25\%) by the method of Laemmli (1970) as described previously (Aliyev et al. 1992). To each slot, $24 \mu \mathrm{g}$ of $\mathrm{Chl}$ were applied. The gels were stained for $30 \mathrm{~min}$ with $0.04 \%(\mathrm{w} / \mathrm{v})$ Coomassie Brilliant Blue G-250 prepared in $3.5 \%$ perchloric acid $\left(\mathrm{HClO}_{4}\right)$.

Statistical analysis: The significance of differences between control and experimental groups were determined by using two-way analysis of variance (ANOVA). Differences in means were considered significant when the $P$-value was $<0.05$. Three different samples for each treatment were taken and analysed twice.

was infected in both personal and experimental gardens. Symptomless plants gave no amplification, while expected $320 \mathrm{bp}$ amplicons were obtained from the infected tomato samples, which were characteristic for Tobamovirus.

Virus-infected tomato plant samples and healthy plants as control were further subjected to the biochemical and physiological analyses.

In our experiments, the MDA content was approximately 1.5-2.0 times higher in the infected plants than that in the healthy plants (Table 2). In the infected leaf samples, a substantial increase in the activities of APO, GPO, and $\mathrm{BPO}$ was found as compared with the leaves of uninfected control plants. Peroxidase activity was high in all stressed plants. GPO activity was higher in infected samples of 1 , 2 , and 3 group and BPO activity was higher in samples of 1, 2, 3, and 5 group (Table 2).

The present investigation revealed enormous changes in antioxidant defence system components in plants due to different virus diseases. Two isoforms of ascorbate peroxidase (APO2, APO3) were observed in healthy plants, whereas a new high-molecular-mass isoform (APO1) emerged in samples infected with Tobamoviruses $(1,3,5)$ (Fig. $2 A)$.

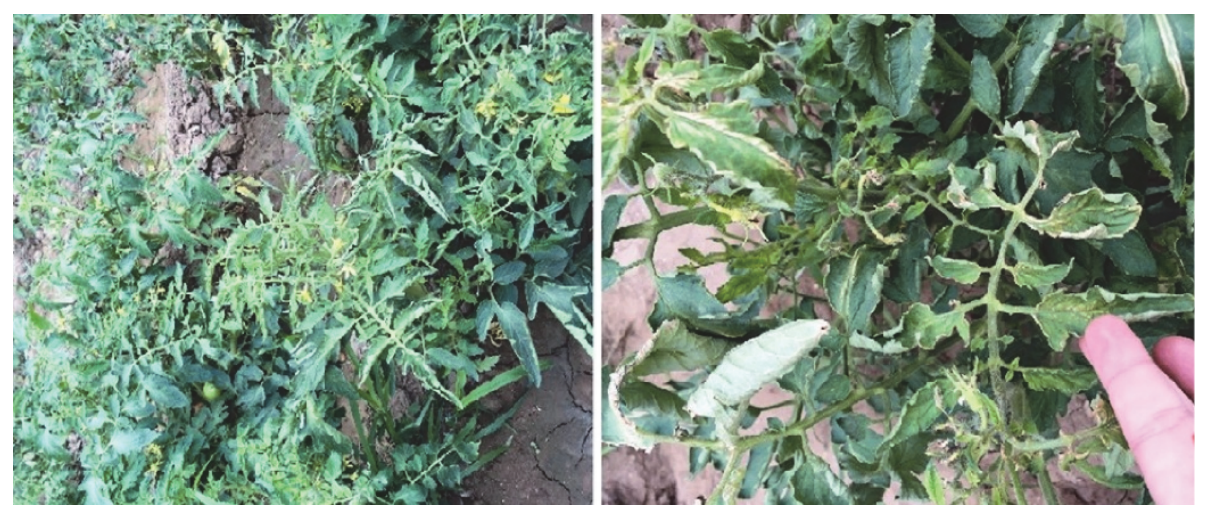

Fig. 1. Early spring symptoms such as shortening the life span, leaf curling, extensive leaf yellowing, stunting leaf deformation, and discolouration in Tobamovirus disease on Solanum lycopersicum L. 
Table 1. Range of absorbance values for positive samples and incidence of Tobamoviruses in surveyed area. ${ }^{*}-$ Distribution of absorbance values at $405 \mathrm{~nm}$. Absorbance values below 0.1 were considered negative samples (samples free of viruses). PMMoV Pepper mild mottle virus; TMV - Tobacco mosaic virus; ToMV - Tomato mosaic virus; CMV - Cucumber mosaic virus; TSWV Tomato spotted wilt virus.

\begin{tabular}{|c|c|c|c|c|c|c|c|c|c|}
\hline \multirow[t]{2}{*}{ DAS-ELISA absorbance values* } & \multirow[t]{2}{*}{ TMV } & \multirow[t]{2}{*}{ ToMV } & \multirow[t]{2}{*}{ PMMoV } & \multicolumn{2}{|c|}{ TMV + PMMoV } & \multicolumn{2}{|c|}{ ToMV + PMMoV } & \multirow[t]{2}{*}{$\mathrm{CMV}$} & \multirow[t]{2}{*}{ TSWV } \\
\hline & & & & TMV & PMMoV & ToMV & PMMoV & & \\
\hline \multicolumn{10}{|l|}{$0.1-0.2$} \\
\hline $0.2-0.5$ & 3 & & & 1 & & 1 & & & \\
\hline $0.5-1.0$ & & 2 & & 1 & 1 & & 1 & & \\
\hline $1.0-1.5$ & 1 & 4 & 1 & & 1 & 1 & 2 & & \\
\hline $1.5-2.0$ & 2 & 3 & 2 & & & 1 & & & \\
\hline $2.0-2.5$ & 2 & & & & & & & & \\
\hline \multicolumn{10}{|l|}{$2.5-3.0$} \\
\hline \multicolumn{10}{|l|}{3.0} \\
\hline No. of total samples & 36 & 36 & 36 & 36 & & 36 & & 36 & 36 \\
\hline No. of infected samples & 8 & 9 & 3 & 2 & & 3 & & 0 & 0 \\
\hline Incidence $[\%]$ & 22.48 & 26.33 & 8.12 & 4.04 & & 8.42 & & 0 & 0 \\
\hline
\end{tabular}

Table 2. Malondialdehyde (MDA) content and activities of peroxidases (guaiacol-type peroxidase, GPO; benzidine-type peroxidase, BPO; ascorbate peroxidase, APO) in virus-infected leaves of tomato plants. Means \pm SD of three replicates. Results of two-way ANOVA analysis: ${ }^{*}, * *, * * *$ significance at the $0.05,0.01$, and 0.001 probability levels, respectively, ns - not significant. FM - fresh mass.

\begin{tabular}{|c|c|c|c|c|}
\hline Plant samples & $\begin{array}{l}\text { MDA } \\
{\left[\mu \mathrm{mol} \mathrm{g}{ }^{-1}(\mathrm{FM})\right]}\end{array}$ & $\begin{array}{l}\text { GPO } \\
{\left[\mu \mathrm{mol} \mathrm{mg} \mathrm{m}^{-1} \text { (protein) } \mathrm{min}^{-1}\right]}\end{array}$ & $\begin{array}{l}\text { BPO } \\
{\left[\mu \mathrm{mol} \mathrm{mg}{ }^{-1} \text { (protein) } \mathrm{min}^{-1}\right]}\end{array}$ & $\begin{array}{l}\text { APO } \\
{\left[\mu \mathrm{mol} \mathrm{mg} \mathrm{m}^{-1} \text { (protein) } \mathrm{min}^{-1}\right]}\end{array}$ \\
\hline Control & $1.46 \pm 0.07$ & $0.06 \pm 0.01$ & $0.86 \pm 0.04$ & $0.20 \pm 0.01$ \\
\hline 1. TMV & $3.17 \pm 0.16$ & $2.27 \pm 0.11$ & $2.32 \pm 0.12$ & $1.60 \pm 0.15$ \\
\hline 2. ToMV & $2.48 \pm 0.07$ & $2.47 \pm 0.12$ & $2.49 \pm 0.12$ & $0.63 \pm 0.03$ \\
\hline 3. PMMoV & $3.29 \pm 0.16$ & $2.49 \pm 0.12$ & $2.96 \pm 0.15$ & $1.71 \pm 0.13$ \\
\hline 4. $\mathrm{TMV}+\mathrm{PMMoV}$ & $2.22 \pm 0.11$ & $1.58 \pm 0.08$ & $1.86 \pm 0.09$ & $0.58 \pm 0.01$ \\
\hline 5. ToMV+PMMoV & $2.29 \pm 0.11$ & $1.13 \pm 0.06$ & $2.96 \pm 0.15$ & $1.54 \pm 0.06$ \\
\hline Control/TBM & $* * *$ & $* * *$ & $* * *$ & $* * *$ \\
\hline Control/ToMV & $* * *$ & $* * *$ & $* * *$ & $* * *$ \\
\hline Control/ PMMoV & $* * *$ & $* * *$ & $* * *$ & $* * *$ \\
\hline Control/TMV+PMMoV & $* * *$ & $* * *$ & $* * *$ & $* * *$ \\
\hline Control/ToMV+PMMoV & $* * *$ & $* * *$ & $* * *$ & $* * *$ \\
\hline TMV/ToMV & $* *$ & ns & ns & $* * *$ \\
\hline TMV/PMMoV & ns & ns & ** & ns \\
\hline TMV/(TMV+PMMoV) & ** & $* * *$ & ** & $* * *$ \\
\hline TMV/(ToMV+PMMoV) & ** & $* * *$ & $* *$ & $\mathrm{~ns}$ \\
\hline ToMV/PMMoV & $* *$ & ns & $*$ & $* * *$ \\
\hline ToMV/(TMV+PMMoV) & * & $* * *$ & ** & ns \\
\hline ToMV/(ToMV+PMMoV) & ns & $* * *$ & $*$ & $* * *$ \\
\hline $\mathrm{PMMoV} /(\mathrm{TMV}+\mathrm{PMMoV})$ & $* * *$ & $* * *$ & $* * *$ & $* * *$ \\
\hline PMMoV/(ToMV+PMMoV) & $* * *$ & $* * *$ & ns & ns \\
\hline TMV+PMMoV/ToMV+PMMoV & ns & $* *$ & $* * *$ & $* * *$ \\
\hline
\end{tabular}

Six low-molecular-mass isoforms of benzidine peroxidase were observed in healthy plant leaves (Fig. 2B). One isoform (BPO2) of average molecular mass emerged in all infected plants. One high-molecular-mass isoform (BPO1) formed in sample 3, and a low-molecular-mass isoform (BPO8) disappeared from sample 4. The results of electrophoretic analysis agreed with the data obtained from colorimetric activity assays (Table 2): the change in peroxidase activity corresponded to the number of polypeptide lines and alterations in their intensities. Thus, lower activity of sample 4 compared to other infected samples might be explained by the disappearance of the isoform BPO8.

Electrophoretic study of isoenzyme content of peroxidase revealed the presence of two isoforms (GPO3, GPO4) of guaiacol peroxidase in the control, four (GPO1, GPO2, GPO3, GPO4) isoforms in sample 3, two isoforms (GPO2, GPO3) in sample 4, and three isoforms (GPO2, GPO3, GPO4) in samples 1 and 5 (Fig. 2C). Constitutive isoforms GPO3 and GPO4 (except for sample 4) were observed in all variants. Depending on the infection degree, the intensities of isoforms GPO3 and GPO4 altered significantly. The intensity of GPO3 isoform 

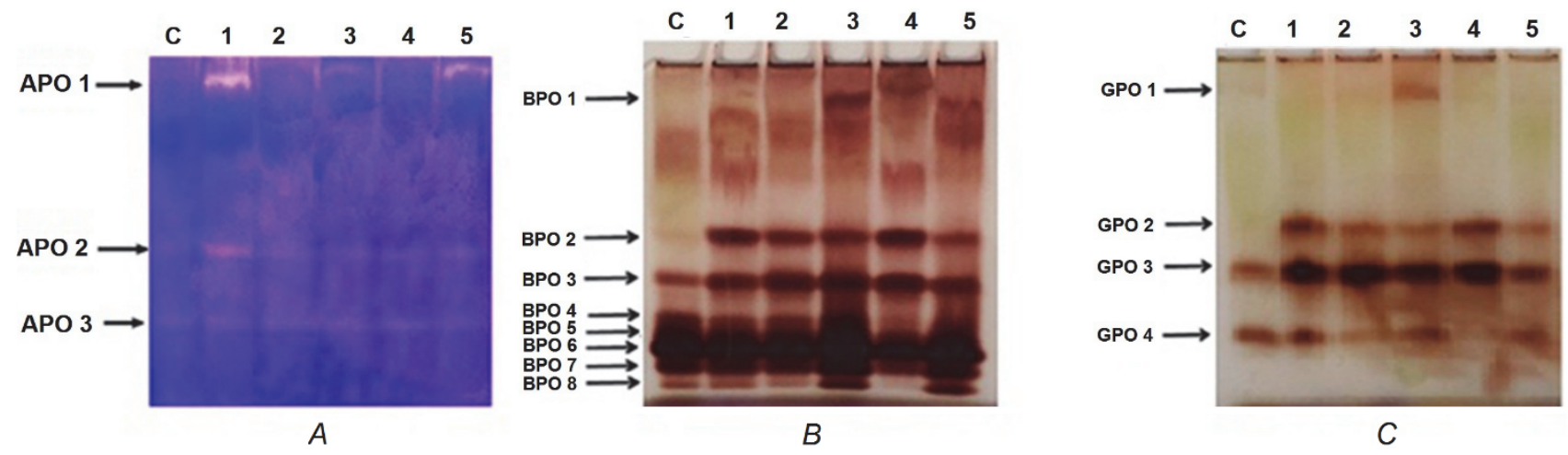

Fig. 2. Isoenzyme profiles of peroxidases in leaves from healthy $(\mathrm{C})$ and Tobamovirus-infected $(1,2,3,4,5)$ tomato plants. $A$, ascorbate peroxidase; $B$ - benzidine peroxidase; $C$ - guaiacol peroxidase. A separating gel of $7 \%$ acrylamide was used for BPO and GPO and $10 \%$ for APO. To each slot, $30 \mu \mathrm{g}$ of proteins in $50 \%$ glycerol with $1 \%$ bromophenol blue were applied. Electrophoresis was carried out for $3 \mathrm{~h}$ at $4^{\circ} \mathrm{C}$ with a steady current of $30 \mathrm{~mA}$.

Table 3. Changes in chlorophyll (Chl), carotenoid (Car), and protein content and Chl stability index in tomato plants under viral stress. Means \pm SD of three replicates. Results of two-way ANOVA analysis: *, **, *** - significance at the $0.05,0.01$, and 0.001 probability levels, respectively; ns - not significant. FM - fresh mass.

\begin{tabular}{|c|c|c|c|c|}
\hline Plant samples & $\mathrm{Chl}(a+b)\left[\mathrm{mg} \mathrm{g}^{-1}(\mathrm{FM})\right]$ & $\operatorname{Car}\left[\mathrm{mg} \mathrm{g}^{-1}(\mathrm{FM})\right]$ & $\begin{array}{l}\text { Chl stability } \\
\text { index [\%] }\end{array}$ & Protein $\left[\mathrm{mg} \mathrm{g}^{-1}(\mathrm{FM})\right]$ \\
\hline Control & $4.66 \pm 0.40$ & $1.72 \pm 0.30$ & - & $8.56 \pm 0.30$ \\
\hline 1. TMV & $3.21 \pm 0.30$ & $1.56 \pm 0.20$ & 68.88 & $6.78 \pm 0.40$ \\
\hline 2. TMV + ToMV & $2.83 \pm 0.20$ & $1.64 \pm 0.10$ & 60.73 & $7.23 \pm 0.50$ \\
\hline 3. PMMoV & $3.64 \pm 0.30$ & $1.82 \pm 0.10$ & 78.11 & $7.45 \pm 0.30$ \\
\hline 4. $\mathrm{TMV}+\mathrm{PMMoV}$ & $2.66 \pm 0.40$ & $1.44 \pm 0.20$ & 57.08 & $6.68 \pm 0.30$ \\
\hline 5. ToMV + PMMoV & $2.92 \pm 0.20$ & $1.78 \pm 0.10$ & 62.66 & $7.04 \pm 0.40$ \\
\hline Control/TMV & $* * *$ & ns & - & $* *$ \\
\hline Control/ToMV & $* * *$ & ns & - & * \\
\hline Control/ PMMoV & $* *$ & ns & - & $*$ \\
\hline Control/TMV+PMMoV & $* * *$ & ns & - & $* *$ \\
\hline Control/ToMV+PMMoV & $* * *$ & ns & - & $* *$ \\
\hline TMV/ToMV & $*$ & ns & - & $\mathrm{ns}$ \\
\hline TMV/PMMoV & $*$ & $*$ & - & $\mathrm{ns}$ \\
\hline TMV/(TMV+PMMoV) & $* *$ & $\mathrm{~ns}$ & - & $\mathrm{ns}$ \\
\hline TMV/(ToMV+PMMoV) & ns & $*$ & - & $\mathrm{ns}$ \\
\hline ToMV/PMMoV & $* *$ & $\mathrm{~ns}$ & - & $\mathrm{ns}$ \\
\hline ToMV/(TMV+PMMoV) & ns & $*$ & - & ns \\
\hline ToMV/(ToMV+PMMoV) & ns & ns & - & $\mathrm{ns}$ \\
\hline PMMoV/(TMV+PMMoV) & $* *$ & $* *$ & - & $\mathrm{ns}$ \\
\hline $\mathrm{PMMoV} /(\mathrm{ToMV}+\mathrm{PMMoV})$ & $* *$ & ns & - & $\mathrm{ns}$ \\
\hline $\mathrm{TMV}+\mathrm{PMMoV} / \mathrm{ToMV}+\mathrm{PMMoV}$ & ns & $* *$ & - & $\mathrm{ns}$ \\
\hline
\end{tabular}

increased and the intesity of GPO4 isoform decreased in stressed plants. The viral infection caused the formation of new isoforms GPO1 and GPO2.

At the same time, some responses of symptomatic plants to viral diseases were also studied. During the pathogenesis, a gradual reduction of $\mathrm{Chl}(a+b)$ was observed in all species. Car content was not significantly affected by Tobamovirus infection. The protein concentration was also low in diseased plants of all species compared with controls (Table 3 ).
The study of the potential quantum yield of photochemical reactions of PSII $\left(\mathrm{F}_{\mathrm{v}} / \mathrm{F}_{\mathrm{m}}\right)$ in plant leaves revealed significant differences between leaves of uninfected and infected plants. The ratio of $F_{v} / F_{m}$ significantly decreased in all infected plants compared with control samples (Table 4).

Since the changes in photosynthetic electron transport activities could be caused primarily by the changes or reorganization of thylakoid components, the thylakoid polypeptide profiles of control and virus-infected leaves were investigated by SDS-PAGE (Fig. 3). 
Table 4. Changes in photochemical activity of Solanum lycopersicum L. in response to viral stress. Means \pm SD of three replicates. Results of two-way ANOVA analysis: *,**,*** - significance at the $0.05,0.01$, and 0.001 probability levels, respectively, ns - not significant. $\mathrm{F}_{0}$ - initial values of chlorophyll fluorescence; $\mathrm{F}_{\mathrm{m}}$ - maximal values of chlorophyll fluorescence; $\mathrm{F}_{\mathrm{v}} / \mathrm{F}_{\mathrm{m}}-$ maximal quantum efficiency of PSII.

\begin{tabular}{|c|c|c|c|}
\hline Plant samples & $\mathrm{F}_{\mathrm{o}}$ & $\mathrm{F}_{\mathrm{m}}$ & $\mathrm{F}_{\mathrm{v}} / \mathrm{F}_{\mathrm{m}}$ \\
\hline Control & $0.21 \pm 0.01$ & $0.76 \pm 0.08$ & 0.72 \\
\hline 1. TMV & $0.27 \pm 0.01$ & $0.62 \pm 0.05$ & 0.56 \\
\hline 2. ToMV & $0.29 \pm 0.01$ & $0.60 \pm 0.07$ & 0.51 \\
\hline 3. PMMoV & $0.38 \pm 0.02$ & $0.64 \pm 0.06$ & 0.41 \\
\hline 4. TMV+PMMoV & $0.24 \pm 0.01$ & $0.53 \pm 0.04$ & 0.55 \\
\hline 5. ToMV+PMMoV & $0.31 \pm 0.02$ & $0.53 \pm 0.04$ & 0.42 \\
\hline Control/TBM & $* *$ & ns & - \\
\hline Control/ToMV & $* * *$ & ns & - \\
\hline Control/ PMMoV & $* * *$ & ns & - \\
\hline Control/TMV+PMMoV & $*$ & $*$ & - \\
\hline Control/ToMV+PMMoV & $* *$ & $*$ & - \\
\hline TMV/ToMV & $* *$ & ns & - \\
\hline TMV/PMMoV & $* *$ & ns & - \\
\hline TMV/(TMV+PMMoV) & $*$ & ns & - \\
\hline TMV/(ToMV+PMMoV) & $*$ & ns & - \\
\hline ToMV/PMMoV & $* *$ & ns & - \\
\hline ToMV/(TMV+PMMoV) & $* *$ & ns & - \\
\hline ToMV/(ToMV+PMMoV) & ns & ns & - \\
\hline PMMoV/(TMV+PMMoV) & $* * *$ & ns & - \\
\hline PMMoV/(ToMV+PMMoV) & $*$ & ns & - \\
\hline TMV+PMMoV/ToMV+PMMoV & $* *$ & ns & - \\
\hline
\end{tabular}

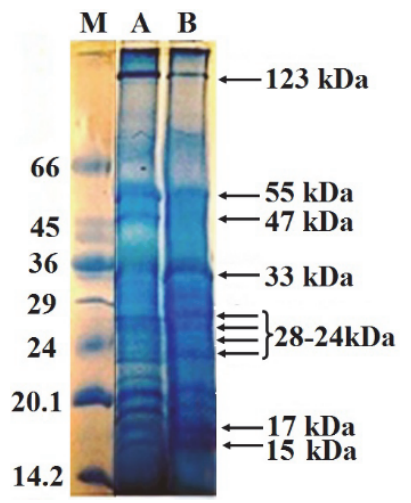

Fig. 3. Coomassie blue stained SDS PAGE polypeptide profiles of thylakoid membranes isolated from control and infected with TMV tomato leaves. A - healthy, B - infected plants; M, standard proteins. To each slot, $24 \mu \mathrm{q}$ of $\mathrm{Chl}$ were applied.

\section{Discussion}

We found that Tobamovirus infection caused an increase in the MDA content, alterations in the activities of peroxidases and quantitative and qualitative changes in their molecular isoforms. A decrease in the content of the PSI polypeptides and Chls were significantly lower in the virus-infected leaves. In addition, a decrease in the activity of PSII was observed which indicated that the Tobamoviruses strongly impaired photosynthesis of tomato plants.
Polypeptide analysis of thylakoid membranes revealed about 25 bands which showed changes in the thylakoid protein profile of the infected plants at 60-15 kDa range. Comparative analysis of the samples showed that the content of PSI (CPI) Chl-protein complex with molecular mass of $123 \mathrm{kDa}$ significantly decreased in the infected variants compared with the control. A comparison of thylakoid polypeptides of the virus-infected leaves with those of the respective controls indicated a decrease in the amount of 55, 47, 33, 28-24, 17, and $15 \mathrm{kDa}$ polypeptides. The synthesis of $\alpha$ - and $\beta$-subunits of the CF1 ATPsynthase complex (atp $A$ and $a t p B$ ) with molecular mass of 55 and $54 \mathrm{kDa}$, respectively, also decreased slightly in the virus-infected samples compared with healthy plants. The intensity of the band in the range of $20-17 \mathrm{kDa}$ also decreased in the infected samples. Such changes were associated with a major decrease in the content of 33 $17 \mathrm{kDa}$ polypeptides.

According to the data of the recently performed experiments, one of the universal responses of plant cells to extreme environmental conditions is the activation of the lipid peroxidation (LPO) process (Kumar and Knowles 1993, Da Costa and Huang 2007, Pandey et al. 2010). The LPO reaction occurs in all cells of the living organisms, particularly in the membrane lipid structures. Organic radicals $\left(\mathrm{R}^{*}\right)$ produced under the influence of different 
stressors immediately react to oxygen molecules forming peroxide radicals $\left(\mathrm{RO}_{2}{ }^{\circ}\right)$, which in turn react to unsaturated lipids and form organic peroxides and new radicals. In other words, peroxidation of lipids occurs, the main indicator of which is the increase in the MDA amount (Huseynova et al. 2015). The amount of peroxide groups is considered to be one of the main markers of the oxidative stress in plants. MDA accumulation is often used as an indicator of lipid peroxidation (Yi et al. 2003). We observed that the infection was accompanied by changes in peroxidase activity and in quantitative and qualitative alterations of their multiple molecular forms. The obtained results suggest that these viruses separately and in the mix caused oxidative stress resulting in the formation of ROS. It led to pronounced changes in plant morphological, physiological, and biochemical parameters. According to the MDA content, which is the main index of the oxidative stress, and the quantity of antioxidant enzymes, these viruses were more dangerous for the plants, when they acted separately (especially PMMoV). The determination of peroxidase activity allowed us to assess plant tolerance against pathogen at early stages of plant development and to speed up the selection work by the exclusion of sensitive varieties. Therefore, our results are in an agreement with those reported by Hernández et al. (2006) who indicated that ROS may function as molecular signals in the induction of defense genes. Several isoforms with different mobilities, observed in the electrophoregram of peroxidase, indicate that these isozymes are coded by different alleles or separate genetic loci. This fact can elucidate functions of isoenzymes of peroxidases encoded by certain genes (Clarke et al. 2002, Mydlarz and Harvell 2007, Sofy 2013).

Reduction of Chl content depending on the duration and severity of infection stages has been reported in other species. In the present study, the decrease in the pigment content might result from the reduced activity of photosynthesis, which led to biochemical, and biophysical changes in the plant cells. Viral disease development in these plants also altered the ratio between Chl $a$ and $b$, and caused significant declines in the Chl stability index, which might affect the photosynthetic efficiency (Huseynova et al. 2014). The variance analysis of the Car content showed that this particular Tobamovirus infection did not significantly affect it. The destruction of membrane structure and decrease in Chl $a$ were observed in leaves inoculated with Obuda pepper virus (ObPV). Whereas in leaves inoculated with ObPV or PMMoV no significant alterations were detected in Chl $b$ amount (Rys et al. 2014). Similar results were observed in virus-infected apple leaves (Bertamini et al. 2003). Chl a was shown to be more sensitive than $\mathrm{Chl} b$ and dependent on the irradiance level of leaves (Christov et al. 2005). There are various theories about how Chl $a$ and $\mathrm{Chl} b$ contents in infected leaves decreased. According to Roca and Minguez-Mosquera (2003) decreases of Chl was the result of increased chlorophyllase activity. On the other hand, Lucas (1998) thought that it could be due to the blocking
Chl biosynthesis. Christov et al. (2005) and Radwan et al. (2007) published similar results for numerous host plants infected with different viruses. Low protein content in diseased samples indicated that the disease might have caused denaturation or breakdown of proteins, as well as polypeptide chains and bound amino acids, resulting in enhanced free amino acid content of the host tissues. The loss of leaf soluble protein in infected leaves would be partially accounted for damaged chloroplast or could be the result of inhibition of protein synthesis (Pineda et al. 2010).

The decrease of $F_{v} / F_{m}$ observed in the infected leaves was also due to decrease in $F_{v}$. This is characteristic for inhibition on the donor side of PSII (Nath et al. 2013, Onda 2013). Specific attention should be paid to the photosynthetic primary reactions and inhibition of the electron transport of PSII, because virus coat protein seems to accumulate in the membranes of chloroplasts and thylakoids of the infected plants. Although the decrease of $\mathrm{Chl}$ was observed in virus-infected tomato plants, $\mathrm{F}_{0}$ were high, indicating that some conformational changes occurred in photosynthetic apparatus after virus infection.

Different authors have reported the inhibition of PSII electron transport in plants suffering from viral infection, and different action mechanisms of the virus in the chloroplast have been proposed. In Cucumber mosaic virus-infected tobacco plants as well as in Peanut green mosaic virus-infected peanut plants, it has been associated with a decrease for polypeptides of the oxygen-evolving complex. Accordingly, the specific PSII electron transport, measured by different Hill reactions in thylakoids isolated from infected leaves, decreased. In the case of $N$. benthamiana infected with PMMoV, decreased amounts of the oxygen-evolving complex proteins - PsbP and PsbQ and mRNAs in the host plant were previously demonstrated (Rahoutei et al. 2000).

The extrinsic proteins of 33 and $17 \mathrm{kDa}$ associated with the luminal surface of the thylakoid membranes are required for optimal functioning of the oxygen evolving machinery. Virus infection induced not only the loss of extrinsic proteins but also a marked loss of $47 \mathrm{kDa}$ polypeptide in thylakoid membranes which may be due to greater disruption of the PSII complex. LHCs play important roles in light absorption, thylakoid stacking, and energy distribution and any damage to these complexes has multiple effects on the photosynthetic system (Klimov et al. 1982). In our experiment, a significant loss of LHCPII (28-24 kDa) polypeptides was observed. This could be a reason for the observed loss of PSII activity and decreased $\mathrm{Chl}$ content in the infected leaves.

Conclusion: In summary, data showed that viral infection caused the decrease in photosynthetic pigments, protein contents, efficiency of PSII, and thylakoid membrane proteins and thereby induced rapid senescence of infected leaves. The obtained data presented in this study suggest that pathogenesis induced oxidative burst in tomato characterized by the increase of MDA concentration. In 
addition, the enhanced activity and expression of some of the new isoforms of peroxidase involved in lignification, compared with control, highlighted the crucial role of these enzymes against phytopathogen attacks and confirmed

\section{References}

Aliyev J., Suleymanov S., Guseinova I. et al.: Effect of specific translation inhibitors on polypeptide composition and spectral characteristics of wheat thylakoid membrane. - Biochemistry 57: 679-686, 1992.

Bertamini M., Grando M.S., Muthuchelian K. et al.: Effect of phytoplasmal infection on PSII efficiency and thylakoid membrane protein changes in field grown apple (Malus Pumila) leaves. - Physiol. Mol. Plant Pathol. 61: 349-356, 2003.

Blancard D., Laterrot H., Marchoux G. et al.: A Colour Handbook - Tomato Diseases: Identification, Biology and Control. Pp. 688. Manson Publishing Limited, London 2012.

Bradford M.M.: A rapid and sensitive method for the quantitation of microgram quantities of protein using the principles of dyebinding. - Anal. Biochem. 72: 143-147, 1976.

Broadbent L.: Epidemiology and control of tomato mosaic virus. - Annu. Rev. Phytopathol. 14: 75-96, 1976.

Christov I., Stefanov D., Velinov T. et al:: The symptomless leaf infection with grapevine leafroll associated virus 3 in grown in vitro plants as a simple model system for investigation of viral effects on photosynthesis. - Plant Physiol. 164: 1124-1133, 2005.

Clarke S.F., Guy P.L., Burritt D.J. et al.: Changes in the activities of antioxidant enzymes in response to virus infection and hormone treatment. - Plant Physiol. 114: 157-164, 2002.

Cuypers A., Vangronsveld J., Ciijsters H.: Peroxidases in roots and primary leaves of Pharsalus vulgaris copper and zinc phytotoxicity: a comparison. - Plant Physiol. 159: 869-876, 2002.

Da Costa M., Huang B.: Changes in antioxidant enzyme activities and lipid peroxidation for bent grass species in response to drought stress. - J. Am. Soc. Hortic. Sci. 132: 319-326, 2007.

Davis B.: Disc electrophoresis. I. Method and application to human serum proteins. - Ann. NY Acad. Sci. 121: 404-427, 1964.

De Gara L., De Pinto M.C., Tommasi F.: The antioxidant systems vis-à-vis reactive oxygen species during plant-pathogen interaction. - Plant Physiol. Bioch. 41: 863-870, 2003.

Díaz-Vivancos P., Clemente-Moreno M.J., Rubio M. et al.: Alteration in the chloroplast metabolism leads to ROS accumulation in pea plants in response to plum pox virus. - J. Exp. Bot. 59: 2147-2160, 2008.

Díaz-Vivancos P., Rubio M., Mesonero V. et al.: The apoplastic antioxidant system in Prunus: response to plum pox virus. - J. Exp. Bot. 57: 3813-3824, 2006.

Gechev T., Gadjiev I., van Breusegem E. et al.: Hydrogen peroxide protects tobacco from oxidative stress by inducing a set of antioxidant enzymes. - Cell Mol. Life Sci. 59: 708-714, 2002.

Gullner G., Künstler A., Király L. et al.: Up-regulated expression of lipoxygenase and divinyl ether synthase genes in pepper leaves inoculated with Tobamoviruses. - Physiol. Mol. Plant Pathol. 74: 387-393, 2010.

Heath RL., Packer L.: Photoperoxidation in isolated chloroplast. I. Kinetics and stoichiometry of fatty acid peroxidation. - Arch. their participation in the defense strategy of the resistant tomato genotype against Tobamovirus infection. These enzymes could be used as a marker in tomato breeding program and in the selection of more tolerant varieties.

Physiol. Biochem. 125: 189-198, 1968.

Helepciuca F.E., Mitoia M.E., Manole-Păunescua A. et al.: Induction of plant antioxidant system by interaction with beneficial and/or pathogenic microorganisms. - Roman. Biotech. Lett. 19: 9366-9375, 2014.

Hernández J.A., Díaz-Vivancos P., Rubio M. et al.: Long-term PPV infection produces an oxidative stress in a susceptible apricot cultivar but not in a resistant cultivar. - Physiol. Plantarum 126: 140-152, 2006.

Huseynova I.M. Sultanova N.F., Aliyev J.A.: Histochemical visualization of ROS and antioxidant response to viral infections of vegetable crops grown in Azerbaijan. - Plant Physiol. Bioch. 81: 26-35, 2014.

Huseynova I.M., Aliyeva D.R., Mammadov A.Ch. et al.: Hydrogen peroxide generation and antioxidant enzyme activities in the leaves and roots of wheat cultivars subjected to long-term soil drought stress. - Photosynth. Res. 125: 279-289, 2015.

Klimov V.V., Allakhverdiev S.I., Shuvalov V.A. et al.: Effect of extraction and re-addition of manganese on light reactions of Photosystem II preparations. - FEBS Lett. 148: 307-312, 1982.

Kumar G., Knowles N.: Changes in lipid peroxidation and lipolytic and free-radical scavenging enzyme during aging and sprouting of potato (Solanum tuberosum L.) seed-tubers. Plant Physiol. 102: 115-124, 1993.

Laemmli U.K.: Cleavage of structural proteins during the assembly of the head of bacteriophage T4. - Nature 227: 680685,1970 .

Lucas J.A.: Plant Pathology and Plant Pathogens, $3^{\text {rd }}$ ed. Pp. 151. Blackwell Science, Oxford 1998.

Mahalingam R., Shah N., Scrymgeour A. et al:: Temporal evolution of the Arabidopsis oxidative stress response. - Plant Mol. Biol. 57: 709-730, 2005.

McKinney G.: Absorption of light by chlorophyll solutions. Biol. Chem. 140: 315-322, 1941.

Mittler R., Zilinskas B.A.: Detection of ascorbate peroxidase activity in native gels by inhibition of the ascorbate-dependent reduction of nitroblue tetrazolium. - Anal. Biochem. 212: 540546, 1993.

Mydlarz L.D., Harvell C.D.: Peroxidase activity and inducibility in the see fan coral exposed to a fungal pathogen. - Comp. Biochem. Phys. A 146: 54-62, 2007.

Nakano Y., Asada K.: Hydrogen peroxide is scavenged by ascorbate-specific peroxidase in spinach chloroplasts. - Plant Cell. Physiol. 22: 867-880, 1981.

Nath K., Jajoo A., Sharma R. et al:: Towards a critical understanding of the photosystem II repair mechanism and its regulation during stress conditions. - FEBS Lett. 587: 3372$3381,2013$.

Oliveira J.T.A., Barreto A.L.H., Vasconcelos I.M. et al.: Role of antioxidant enzymes, hydrogen peroxide and PR proteins in the compatible and incompatible interactions of cowpea (Vigna unguiculata) genotypes with the fungus colletotrichum gloeosporioides. - J. Plant Physiol. Pathol. 2: 3, 2014.

Onda Y.: Oxidative protein-folding systems in plant cells. - Int. 
J. Cell Biol. 2013: 44-59, 2013.

Pandey H.C., Baig M.J., Chandra A. et al.: Drought stress induced changes in lipid peroxidation and antioxidant system in genus Avena. - J. Environ. Biol. 31: 435-440, 2010.

Pérez-Bueno M.L., Ciscato M., VandeVen M. et al:: Imaging viral infection. Studies on Nicotiana benthamiana plants infected with the Pepper mild mottle tobamovirus. Photosynth. Res. 90: 11-24, 2006.

Pineda M., Sajnani C., Barón M.: Changes induced by the pepper mild mottle tobamovirus on the chloroplast proteome of Nicotiana benthamiana. - Photosynth. Res. 103: 31-45, 2010.

Radotić K., Dučić T., Mutavdžić D.: Changes in peroxidase activity and isoenzymes in spruce needles after exposure to different concentrations of cadmium. - Environ. Exp. Bot. 44: 105-113, 2000.

Radwan D.E.M., Fayez K.A., Mahmoud S.Y. et al.: Physiological and metabolic changes of Cucurbita pepo leaves in response to Zucchini yellow mosaic virus (ZYMV) infection and salicylic acid treatments. - Plant Physiol. Bioch. 45: 480489, 2007.

Rahoutei J., García-Luque I., Barón M.: Inhibition of photosynthesis by viral infection: effect on PSII structure and function. - Physiol. Plantarum 110: 286-292, 2000.

Rao G.S., Rao Reddy N.N., Surekha C.: Induction of plant systemic resistance in legumes Cajanus cajan, Vigna radiata, Vigna mingo against plant pathogens Fusarium oxysporum and Alternaria altermata - a Trichoderma viride mediated reprogramming of plant defense mechanism. - Int. J. Recent Sci. Res. 6: 4270-4280, 2015.

Riedle-Bauer M.: Role of reactive oxygen species and antioxidant enzymes in systemic virus infections of plants. - J. Phytopathol. 148: 297-302, 2000.
Roca M., Minguez-Mosquera M.I.: Involvement of chlorophyllase in chlorophyll metabolism in olive varieties with high and low chlorophyll content. - Physiol. Plantarum 117: 459466, 2003.

Rys M., Juhász C., Surówka E. et al.: Comparison of a compatible and an incompatible pepper-tobamovirus interaction by biochemical and non-invasive techniques: chlorophyll $a$ fluorescence, isothermal calorimetry and FTRaman spectroscopy. - Plant Physiol. Bioch. 83: 267-278, 2014.

Sairam R.K., Deshmukh P.S., Shukla D.S.: Tolerance of drought and temperature stress in relation to increased antioxidant enzyme activity in wheat. - J. Agron. Crop Sci. 178: 171-178, 1997.

Sajnani C., Zurita J.Z., Roncel M. et al.: Changes in photosynthetic metabolism induced by tobamovirus infection in Nicotiana benthamiana studied in vivo by chlorophyll thermoluminescence. - New Phytol. 175: 120-130, 2007.

Sofy A.R., Mahfouze S.A., El-Enany M.A.M.: Isozyme markers for response of wild potato species to potato spindle tuber viroid Egyptian isolate. - World Appl. Sci. J. 27: 1010-1022, 2013.

Takahashi S., Murata N.: How do environmental stresses accelerate photoinhibition? - Trend. Plant Sci. 13: 178-182, 2008.

Torres M.A., Jones J.D.G., Dangl J.L.: Reactive oxygen species signaling in response to pathogens. - Plant Physiol. 141: 373378, 2006.

Yi S., Yu S., Choi D.: Involvement of hydrogen peroxide in repression of catalase in TMV-infected resistant tobacco. Mol. Cells 15: 364-369, 2003. 